\title{
Correlation links of physiological groups of microorganisms with fertility indicators of degraded chernozem for different fertilizer systems
}

\author{
Demydenko O. \\ Cherkasy State Agricultural Research Station of NSC "Institute of Agriculture of NAAS" \\ 13, Dokuchayeva Str., Kholodnianske village, Cherkasy region, Cherkasy oblast, Ukraine, 20731 \\ e-mail: smilachiapv@ukr.net
}

\begin{abstract}
Goal. To develop a comparative correlation model of the interconnections of ecological-trophic groups of soil microorganisms with agrophysical, physicochemical indicators, humus condition, the productivity of the degraded chernozem and to determine the energy efficiency of the use of intensive, low-intensive, and organic fertilizer systems using the by-products of crops as organic fertilizers in the 5-field grain-spray crop rotation for the conditions of the Central Right-Bank Forest-Steppe. Methods. Field and laboratory experiments, statistically analytical method. Results. Taking into account that use of the intensive fertilization system causes an overdrying of a layer of degraded chernozem $0-20 \mathrm{~cm}$, and the use of an organic system increases the level of moisture, it can be argued that the best conditions for preserving the organic substance of humus are created for an organic fertilizer system. For organic and low-cost fertilization systems, the saturation of the soil complex $\mathrm{Ca} 2+$ is carried out by reducing the chemical load on chernozem. That leads to a decrease in the level of metabolic acidity and amplification of biogenicity due to the growth of the number and activity of ammonifying, amylolytic, pedotrophenic, oligotrophic microorganisms and the decrease in the activity of the humus-extraction groups of microorganisms, which provides reproduction of humus in the agrocnosis of short-crop rotation. Conclusions. For an intensive fertilizer system, the density of the structure increases when the drainage of soil conditions increases, which enhances the process of mineralization of humus due to the growth of the activity of humus extraction microorganisms. For organic and low-intensive fertilizer systems, there is a loosening of a $0-20 \mathrm{~cm}$ layer of chernozem, which stimulates the increase in the activity of ammonifying and pedotrophemical groups of microorganisms. To a lesser extent, it influences the biogenicity and activity of amylolytic and oligotrophic groups of microorganisms.
\end{abstract}

Key words: pedotroph, oligotroph, organic agriculture, soil microbiota, energy efficiency, productivity.

DOI: https://doi.org/10.31073/agrovisnyk202104-03

In modern agriculture of the Forest-Steppe zone of Ukraine there is an increasing human intervention in natural processes, which leads to changes in the functioning of soil agroecosystems. Anthropogenic impact on the agroecosystem should be assessed on the basis of many soil indicators, which include the reaction of soil microorganisms [1-2], which are actively involved in the decomposition of plant residues, nitrogen fixation, stabilization of soil phytosanitary conditions and accumulation of active substances [3- 4].

Organic farming is a management system, the purpose of which is a balance between the productivity of the agrocenosis and environmental degradation in order to ensure the preservation of soil quality [5-6]. The General Assembly of the International Federation of Organic Agriculture Movements (IFOAM, 2005) has adopted basic principles, one of which is the principle of health: organic agriculture is designed to maintain and improve the condition of soil, flora and fauna as indivisible whole; the health of people and their communities cannot be separated from the health of ecosystems, because a healthy crop is formed on healthy soil, which supports the health of animals and humans;

Organic farming is a management system, the purpose of which is a balance between the productivity of the agrocenosis and environmental degradation in order to ensure the preservation of soil quality [5-6]. The General Assembly of the International Federation of Organic Agriculture Movements (IFOAM, 2005) has adopted basic principles, one of which is the principle of health: organic agriculture is designed to maintain and improve the condition of soil, flora and fauna as indivisible whole; the health of people and their communities cannot be separated from the health of ecosystems, because a healthy crop is formed on healthy soil, which supports the health of animals and humans;

Analysis of recent research. The results of long-term research show that intensive agriculture leads to mineralization of soil organic matter and, as a consequence, changes biodiversity, increases the emission of greenhouse gases $(\mathrm{CO} 2, \mathrm{CH} 4, \mathrm{~N} 2 \mathrm{O})$ from the soil due to humus mineralization [5, 7]. In the process of transition to organic farming, the content of organic matter in the soil is first restored, and later even increases [8], the number of easily accessible forms of nitrogen decreases, but its total content increases and taxonomic and functional soil biodiversity increases $[9,10]$. microbial biomass and its activity, first of all, the number of nitrogenfixing bacteria and mycorrhizal fungi [11]. As a result, the structure of the soil, aggregate composition, water holding capacity and cation exchange capacity and humus state change and improve, which contributes to soil loosening and the development of soil mesofauna [12]. In general, the soil in agroecosystems in organic farming is most consistent with healthy soil $[5,13,14]$.

In the transition from intensive to organic farming there are several agroecological and technological stages [15]. The most noticeable is the spread of low input agrotechnology, which consists in moderate, reduced, limited 
use of mineral fertilizers, and then complete abandonment of them with the increasing use of organic fertilizers in the form of manure, green manure, or the use of by-products as organic fertilizer. The simplest way to maintain soil health in organic farming systems is to follow all the recommendations for ensuring its fertility: - crop rotation, crops of symbiotrophic crops, green manure, etc. [16].

Oligotrophication of agroecosystems with an organic fertilizer system, as a way to rehabilitate and maintain soil health should (and should!) Be used to support and rehabilitate the soil ecosystem [5]. In an oligotrophic soil ecosystem, the concentration of easily utilized forms of biophilic elements $(C, N, P, K$, etc.) is insignificant, while their gross content, diversity and numbers of biota are relatively high [17]. Organic farming is a special, knowledgeintensive technological system of agriculture, agroecologically tolerant to the soil agroecosystem. The concept of soil quality and soil fertility is supplemented by a new category - soil health, and gives importance to the most important, general soil characteristics, because soil quality (health) is mainly humus, agrophysical and physicochemical characteristics of soil agroecosystems, and fertility - its consumer component [13].

The relationship between physical, physicochemical properties and humus of chernozem with the activity of soil and biological processes in different fertilizer systems in the transition from intensive to organic farming, occupy an important but insufficiently studied place in research [11]. In this regard, the establishment of the relationship between physical, physicochemical properties of chernozems with the intensity of soil-biological processes in the study of soil biodynamics for different fertilizer systems, which reflects the state of the system "soil - microorganisms - plants", is becoming increasingly relevance.

The aim of the study. To develop a comparative correlation model of relationships of physiological groups of soil microorganisms with agrophysical, physicochemical parameters, humus condition, productivity of podzolic chernozem using by-products of crops as organic fertilizers in the 5-field grain-row crop rotation of Ukraine.

Materials and methods of research. The research was conducted in a stationary field experiment of the Cherkasy State Agricultural Research Station NSC "Institute of Agriculture NAAS", laid in 2010 on an area of 0.75 ha number of fields 5 with a size of $30 \mathrm{~m} 2$, the plot contains four repetitions. The experiment studies rotational crop rotation with saturation of cereals, legumes and industrial crops. Soil - chernozem degraded in the carbonate forest. The content of humus in the arable layer is $2.76-3.22 \%$ according to Tyurin, the sum of absorbed bases is 24.5-28.1 mg.-eq. per $100 \mathrm{~g}$ of soil, hydrolytic acidity $1.99-2.19 \mathrm{mg}$.-eq. $100 \mathrm{~g}$ of soil, pH of salt extract - 6,0-7,1. The degree of saturation of bases is $92.8-93.3 \%$, the content of mobile forms of phosphorus (according to Truog) - $9.0 \mathrm{mg}$ per $100 \mathrm{~g}$ of soil, exchangeable potassium (according to Brovkina) - $12 \mathrm{mg}$ per $100 \mathrm{~g}$ of soil.

Tillage system in crop rotation: surface tillage with disc implements, shelfless tillage to the depth of plowing and plowing. The experiment studied a 5-type grain-row crop rotation: peas - winter wheat - corn - soybeans spring barley. The saturation of legumes is $40 \%$.

Intensive system (organo-mineral) fertilizer provides the following doses of fertilizers: peas $\mathrm{N}_{30} \mathrm{P}_{50} \mathrm{~K}_{50}$, winter wheat $-\mathrm{N}_{30} \mathrm{P}_{90} \mathrm{~K}_{90}+\mathrm{N}_{50}+\mathrm{N}_{40}$, soybeans $-\mathrm{N}_{20} \mathrm{P}_{60} \mathrm{~K}_{60}+\mathrm{N}_{40}$. Corn $-\mathrm{N}_{20} \mathrm{P}_{90} \mathrm{~K}_{90}+\mathrm{N}_{100}$, spring barley $-\mathrm{N}_{20} \mathrm{P}_{80} \mathrm{~K}_{80}$.

The low-consumption fertilizer system provides the following doses of fertilizers: peas $-\mathrm{N}_{30} \mathrm{P}_{30} \mathrm{~K}_{30}$, winter wheat $-\mathrm{N}_{30} \mathrm{P}_{60} \mathrm{~K}_{60}+\mathrm{N}_{30}$, soybeans $-\mathrm{N}_{20} \mathrm{P}_{40} \mathrm{~K}_{40}$. Corn $-\mathrm{N}_{60} \mathrm{P}_{70} \mathrm{~K}_{60}+\mathrm{N}_{20}$, spring barley $-\mathrm{N}_{40} \mathrm{P}_{40} \mathrm{~K}_{40}+\mathrm{N}_{25}$.

Organic fertilizer system: without mineral fertilizers and using by-products of the predecessor as fertilizer (14 t/ha), with grain treatment with nitrogen-fixing, phosphorus-mobilizing biological preparations, growth regulators, humates and fertilization with humates, plant growth regulator or biological product.

To study the physicochemical and agrochemical parameters, mixed soil samples (12-14 individual samples) were taken with a cane drill from a depth of 0-20 cm with subsequent preparation for analysis in accordance with DSTU ISO 11464-2001. Soil moisture - thermogravimetric method for the main periods of crop growth (DSTU ISO 11465: 2001); particle size distribution - according to NA Kaczynski (DSTU 4730:2007), density of addition (structure) - by the method of cutting rings in the modification of NA Kaczynski (DSTU ISO 11272:2001); pHKI potentiometrically (DSTU ISO 10390:2007); hydrolytic acidity - according to G. Kappen in the modification of CINAO (GOST26212-91); the amount of absorbed bases - Kappen-Gilkovytsia method (GOST 27821-88); the degree of saturation of the bases - estimated. The content of humus in IV Tyurin in the modification of VM Simakov was determined in soil samples (DSTU 4289:2004); labile organic matter (DSTU 4732:2007).

Selection, preparation and storage of soil samples for the study of aerobic microbiota in the laboratory were performed in accordance with DSTU ISO 10381 - 6-2001. Determination of the number of different groups of soil microorganisms was performed according to the method of DG Zvyagintsev by sowing the soil suspension on solid nutrient media. Meat-peptone agar (MPA) was used to determine the total number of microorganisms that decompose organic compounds that contain nitrogen. Microorganisms that assimilate mineral forms of nitrogen were determined on starch-ammonia medium (KAA). Counting, isolation of bacteria and actinomycetes was performed by surface sowing of $0.05 \mathrm{ml}$ of soil suspension from the fourth dilution on Zvyagintsev's medium. The number of microorganisms that destroy cellulose was calculated on Hutchinson's medium with fiber, polysaccharides were synthesized on Martin's medium, melanins were synthesized on Chapek's medium at $\mathrm{pH}=$ 5.0 , humates were decomposed on sodium humate, and pedotrophs on soil. The direction of microbial processes in the soil was assessed using the coefficients of mineralization-immobilization of nitrogen, oligotrophic, pedotrophic, transformation of soil organic matter. The level of energy efficiency of production was calculated by OV Kalinichenko [19]. Statistical processing of experimental data was performed according to generally accepted methods in soil science and soil microbiology using computer programs Microsoft Excel and Statistica 10.

Research results. Correlation dependence of physiological groups of soil microorganisms with chernozem moisture in the layer of $0-20 \mathrm{~cm}$ shows a direct correlation at the level of strong correlation $(R=+0.85-0.90 \pm$ $0.03 ; R^{2}=0.73-0.81$ ) with ammonifying, pedotrophic microorganisms, and their number by $73-81 \%$ is determined by the level of moisture $0-20 \mathrm{~cm}$ layer of chernozem (Table 1). The dependence between soil moisture and micromycetes decreases to the correlation of the average level $\left(R=+0.61 \pm 0.03 ; R^{2}=0.31\right)$, and moisture 
determines their number by $31 \%$. The number of humate-decomposing microorganisms with a moisture factor was at the level of inverse strong correlation $\left(R=-0.84 \pm 0.02 ; R^{2}=0.72\right)$, and a decrease in the level of humidity by $1 \%$ contributed to an increase in the number of this group of microorganisms by 0.06 million. CFU (1)/g of soil. The least number of amylolytic and oligotrophic groups of microorganisms reacted to the change in humidity of 0 $20 \mathrm{~cm}$ layer of chernozem: $\mathrm{R}=-0.28-0.39 \pm 0.02 ; \mathrm{R}^{2}=0.08-0.15$.

A direct correlation was found between the moisture level and the biogenicity of chernozem $(R=+0.79 \pm 0.02$; $\left.\mathrm{R}^{2}=0.62\right)$. The growth of biogenicity is determined by the activity and number of ammonifying, pedotrophic and the number of micromycetes in the soil, the connection of which with the level of moisture was also at the level of direct strong correlation (Table 1).

1. Dependence between agrophysical indicators and the number of physiological groups of microorganisms

\begin{tabular}{|c|c|c|c|}
\hline \multirow[b]{2}{*}{ Group of microorganisms } & \multirow{2}{*}{$\begin{array}{l}\text { Regression equation } \\
\qquad y=a x \pm c\end{array}$} & \multicolumn{2}{|c|}{ Odds: } \\
\hline & & $\begin{array}{c}\text { correlations, } \\
\mathrm{R} \\
\end{array}$ & $\begin{array}{l}\text { determination, } \\
\mathrm{R}^{2}\end{array}$ \\
\hline \multicolumn{4}{|c|}{ Щільність будови, г/см³ } \\
\hline Ammonifying & $y=1499,8-1150 x$ & $-0,84$ & 0,71 \\
\hline Amylolytic & $y=236,8-175 x$ & $-0,55$ & 0,30 \\
\hline Pedotrophic & $y=2292,4-1775 x$ & $-0,87$ & 0,75 \\
\hline Oligotrophic & $y=241,1-185,3 x$ & $-0,45$ & 0,21 \\
\hline Micromycetes & $y=1178,6-825 x$ & $-0,69$ & 0,48 \\
\hline Humatodecomposing & $y=-10,7+8,75 x$ & $+0,85$ & 0,72 \\
\hline Biogenicity & $y=4272,6-3287 x$ & $-0,85$ & 0,72 \\
\hline \multicolumn{4}{|c|}{ Вологість ґрунту, \% } \\
\hline Ammonifying & $y=-97,8+8,73 x$ & $+0,88$ & 0,77 \\
\hline Amylolytic & $y=-2,26+1,11 x$ & $+0,, 45$ & 0,20 \\
\hline Pedotrophic & $y=-168,5+13,21 x$ & $+0,83$ & 0,69 \\
\hline Oligotrophic & $y=-10,1+1,07 x$ & $+0,30$ & 0,09 \\
\hline Micromycetes & $y=42,2+5,7 x$ & $+0,61$ & 0,34 \\
\hline Humatodecomposing & $y=1,44-0,067 x$ & $-0,83$ & 0,68 \\
\hline Biogenicity & $y=-279,5+24,1 x$ & $+0,79$ & 0,62 \\
\hline
\end{tabular}

By a similar principle, the relationship between the level of humidity and the coefficient of pedotrophic (Kpdt) $\left(R=0.68 \pm 0.02 ; R^{2}=0.46\right)$, and the coefficient of mineralization of immobilization $(\mathrm{Km} / \mathrm{i})$ with the level of humidity correlates at the level of inverse strong correlation $\left(R=-0.76 \pm 0.02 ; R^{2}=0.58\right)$ and is associated with an increase in the number of humate-decomposing microorganisms.

Calculation of correlations of different physiological groups of microorganisms with a structure density in the 0-20 cm layer of chernozem showed that the number of amino-fixing, pedotrophic microorganisms with a structure density correlated at the level of inverse strong correlation $\left(R=-0.85-0.88 \pm 0,03 ; R^{2}=0,73-0,79\right)$, and the number of micromycetes - at the level of inverse correlation of the average level: $R=-0,61 \pm 0,02 ; R^{2}=0.37$. The increase or decrease in the density of the structure in the layer of $0-20 \mathrm{~cm}$ determines by $71-73 \%$ the number of ammonifying and pedotrophic microorganisms, and micromycetes - by $37 \%$ (table 2 ).

2. The relationship between physicochemical parameters and the number of ecological and trophic groups of microorganisms in the $0-20 \mathrm{~cm}$ layer of podzolic chernozem

\begin{tabular}{|c|c|c|c|}
\hline \multirow{2}{*}{ Group of microorganisms } & \multirow{2}{*}{$\begin{array}{l}\text { Regression equation } \\
\qquad y=a x \pm c\end{array}$} & \multicolumn{2}{|c|}{ Odds: } \\
\hline & & $\begin{array}{c}\text { correlations, } \\
\mathrm{R}\end{array}$ & $\begin{array}{c}\text { determination, } \\
\mathrm{R}^{2}\end{array}$ \\
\hline \multicolumn{4}{|c|}{$\mathrm{pH}_{\text {сл }}$} \\
\hline Ammonifying & $y=-359,4+73,4 x$ & $+0,7$ & 0,76 \\
\hline Amylolytic & $y=-54,1+12,5 x$ & $+0,58$ & 0,34 \\
\hline Pedotrophic & $y=-587+114,9 x$ & $+0,83$ & 0,69 \\
\hline Oligotrophic & $y=-70,3+13,9 x$ & $+0,48$ & 0,24 \\
\hline Micromycetes & $y=-173,9+55,9 x$ & $+0,76$ & 0,57 \\
\hline Humatodecomposing & $y=3,39-0,56 x$ & $-0,88$ & 0,77 \\
\hline Biogenicity & $y=-1071,8+214,6 x$ & $+0,89$ & 0,79 \\
\hline \multicolumn{4}{|c|}{ Сума поглинутих основ, мг-екв на 100 г ґрунту } \\
\hline Ammonifying & $y=-259,7+11,5 x$ & $+0,85$ & 0,72 \\
\hline Amylolytic & $y=-31,0+1,75 x$ & $+0,55$ & 0,39 \\
\hline Pedotrophic & $y=-423,3+17,8 x$ & $+0,89$ & 0,79 \\
\hline Oligotrophic & $y=-42,2+1,85 x$ & $+0,45$ & 0,28 \\
\hline Micromycetes & $y=-83,7+8,25 x$ & $+0,71$ & 0,58 \\
\hline
\end{tabular}




\begin{tabular}{|l|c|c|c|}
\hline Humatodecomposing & $\mathrm{y}=2,66-0,09 \mathrm{x}$ & $-0,87$ & 0,75 \\
\hline Biogenicity & $\mathrm{y}=-757,3-32,9 \mathrm{x}$ & $+0,86$ & 0,74 \\
\hline
\end{tabular}

The biogenicity of $0-20 \mathrm{~cm}$ of the chernozem layer is subject to the established regularity: the connection with the moisture level was at the level of direct strong correlation $\left(R=0.86 \pm 0.03 ; R^{2}=0.74\right)$. A direct strong correlation $\left(R=0.70-0.86 \pm 0.02 ; R^{2}=0.49-0.74\right)$ was established between the density of the structure and the content of humanodegradable microorganisms and $\mathrm{Km} / \mathrm{i}$ (mineralization / immobilization coefficient).

The relationship between the number of ecological and trophic groups of microorganisms and physicochemical parameters: metabolic and hydrolytic acidity and the amount of absorbed bases (Table 2).

It was found that a direct strong correlation $\left(R=+0.76-0.82 \pm 0.03 ; R^{2}=0.57-0.67\right)$ was found between metabolic acidity $(\mathrm{pHNI})$ and the number of ammonifiers, pedotrophs and micromycetes, and with amylolytic and oligotrophic groups of microorganisms, the correlation was weakened to a direct average level $(R=+0.49-0.58$ $\left.\pm 0.02 ; R^{2}=0.24-0.34\right)$. The level of soil biogenicity with metabolic acidity was correlated at the level of direct strong correlation $\left(R=+0.82 \pm 0.03 ; R^{2}=0.67\right)$, which is associated with an increase in the number and activity of ammonifying, pedotrophic, to a greater extent, and amylolytic groups microorganisms and micromycetes, to a lesser extent.

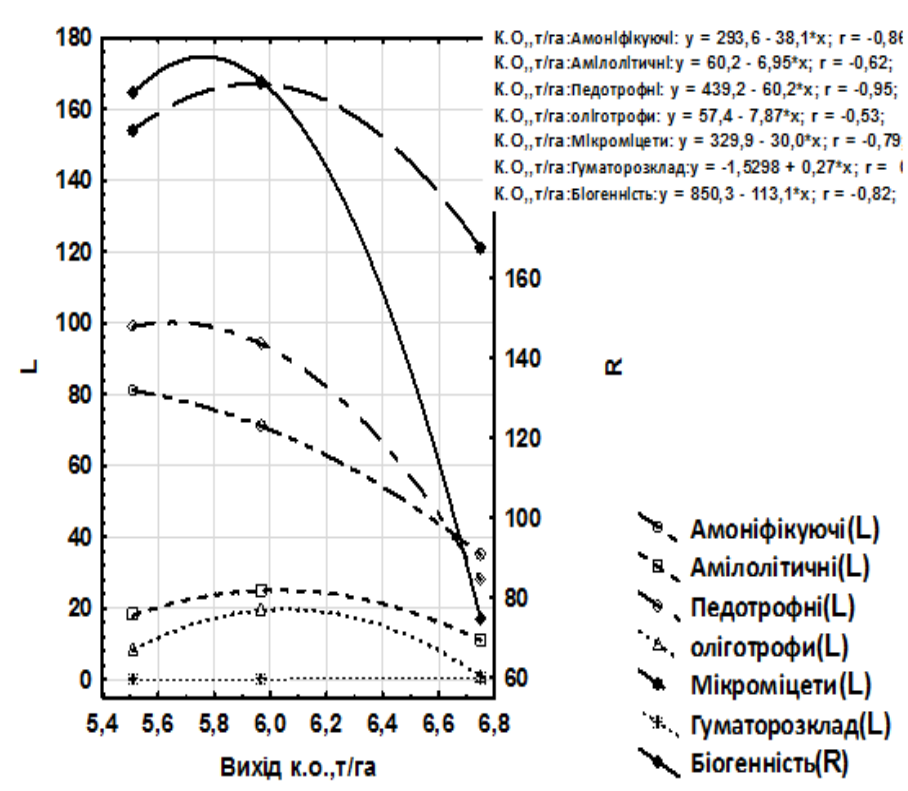

The relationship between the yield of feed units in crop rotation and the number of ecological and trophic groups of microorganisms in chernozem podzolic strongly degraded

The correlation dependence between productivity of crop rotations on an output of k. per 1 ha with different groups of soil microorganisms. It was found that between the release of $\mathrm{k}$. $\mathrm{O}$. and ammonifying, pedotrophic and myxomycetes, biogenicity and pedotrophic coefficient revealed an inverse strong correlation $(R=-0.79-0.87 \pm$ $0.02 ; \mathrm{R} 2=0.62-0.76$ ), and with amylolytic and oligotrophic groups of microorganisms The language was at the level of the inverse correlation of the middle level. Per unit of increase or decrease in productivity at the output of k.o. accounted for 30-60 and 6.9-7.0 units of the number of these groups of microorganisms. The growth of the yield to. per 1 ha of crop rotation correlated at the level of direct strong correlation with the content of humusdecomposing microorganisms $(R=0.86 \pm 0.03$; $R 2=0.74)$, and with the coefficient of mineralization of immobilization the connection weakened to the average level of correlation (Fig.).

\section{References}

1. Menkina, Ye.A., Voropaeva, A.A. (2018). Izmenenie agrokhimicheskikh i mikrobiologicheskikh svoystv chernozema obyknovennogo pri raznykh tekhnologiyakh vozdelyvaniya ozimoy pshenitsy [Changes in agrochemical and microbiological properties of common chernozem in different technologies of winter wheat cultivation] Agricultural Journal, 1 (11), 35 - 42. doi: 10.25930/0372-3054-2018-1-11- 41-500 [in Russian].

2. Tsigichko, A.A. (2017). Vliyanie dlitelnogo ispolzovaniya organicheskoy sistemy zemledeliya na strukturno-funktsionalnoe sostoyanie chernozema opodzolennogo Levoberezhnoy Lesostepi Ukrainy [The influence of long-term use of the organic farming system on the structural and functional state of the podzolized chernozem of the Left Bank Forest-Steppe of Ukraine]. News of the Gomel State University named after F. Skorina. Ser. Natural Sciences, 69 (105), 61 - 68. [in Russian].

3. Kutovaya, O.V., Grebennikov, A.M., Cheverdin, Yu.I., Markina, L. G. (2017). Vliyanie dlitelnosti ispolzovaniya agrochernozemov $v$ zemledelii na mezofaunu i aktivnost mikroflory [Influence of the duration of the use of agrochernozems in agriculture on the mesofauna and microflora activity]. Agrarian Russia, 1, 2 - 9. [in Russian]. 
4. Menkina, Ye.A., Kuprichenkov, M.T. (2018). Sezonnaya dinamika biologicheskoy aktivnosti v agro- $\mathrm{i}$ biogennykh pochvakh Stavropolskogo kraya [Seasonal dynamics of biological activity in agro- and biogenic soils of the Stavropol Territory]. Tavrichesky Bulletin of Agrarian Science, 2 (14), 64 - 76. [in Russian].

5. Van Bruggen, A.H.C., Semenov, A.M. (Finckh, M.R., Van Bruggen, A.H.C., Tamm, L. (Ed.)). (2015). Soil health and soilborne diseases in organic agriculture. Plant Diseases and Their Management in Organic Agriculture. APS PRESS.

6. Glinushkin, A.P., Sokolov, M.S., Toropova, Ye.Yu. (2016). Zdorovaya pochva i ee vosproizvodstvo v alternativnykh sistemakh zemledeliya [Healthy soil and its reproduction in alternative farming systems. Phytosanitary and hygienic requirements for healthy soil]. Moscow: Agrorus. [in Russian].

7. Tsyhichko, H. O., Siabruk, O.P. (2016). Vplyv tradytsiinoi ta orhanichnoi system zemlerobstva na dynamiku emisii vuhlekysloho hazu ta fermentatyvnu aktyvnist chornozemu opidzolenoho [Influence of traditional and organic farming systems on the dynamics of carbon dioxide emissions and enzymatic activity of podzolic chernozem]. Agrochemistry and soil science, 85, 82 - 87. [in Ukrainian].

8. Franzluebbers, A.J., Hons, F.M., Zuberer, D.A. (1995). Soil organic carbon, microbial biomass and mineralisable carbon and nitrogen in sorghum. Soil Sci. Soc. Am. J., 59, 460 - 466.

9. Garbeva, P., Van Veen, J.A., Van Elsas, J.D. (2004). Microbial diversity in soil: selection of microbial populations by plant and soil type and implications for disease suppressiveness. Ann Rev Phytopath, 42, $243-270$.

10. Muder, P., Fließbach, A., Dubois, D. et al. (2002). Soil Fertility and Biodiversity in Organic Farming. Science, 296 (5573), 1694 - 1697.

11. Drury, C.F., Stone, J.A., Findlay, W.I. (1991). Microbial biomass and soil structure associated with corn, grass and legumes. Soil Sci. Soc. Am. J., 55, $805-811$.

12. Ferris, H., Tuomisto, H. (2015). Unearthing the role of biological diversity in soil health. Soil Biology and Biochemistry, 85, $101-109$.

13. Semenov, A.M., Semenov, V.M., Van Bruggen, A.Kh.K. (2011). Diagnostika zdorovya i kachestva pochvy [Diagnostics of soil health and quality]. Agrochemistry, 12, $4-20$. [in Russian].

14. Sokolov, M.S., Glinushkin, A.P., Toropova, Ye.Yu. et al. (2015). Zdorovaya pochva — fitosanitarnyy bazis bespestitsidnogo rastenievodstva [Healthy soil is a phytosanitary basis for pesticide-free crop production]. RJOAS, 12(48), 3 - 9. [in Russian].

15. Buyer, J.S., Kaufman, D.D. (1996). Microbial diversity in the rhizosphere of corn grown under conventional and low-input systems. Appl. Soil Ecol., 5, $21-27$.

16. Saiko, V.F. (1999). Zemlerobstvo KhKhl stolittia: problemy ta shliakhy vyrishennia [Agriculture of the XXI century: problems and solutions]. Coll. Science. Proceedings of the Institute of Agriculture UAAS, 23 - 29. [in Ukrainian].

17. O'Neill, R.V., De Angeles, D.L., Waide, J.B., Allen, T.F.H. (1986). A hierarchical concept of ecosystems. Princeton: Princeton Univ. Press. 